\title{
Rhizosphere Microbiome of Arid Land Medicinal Plants and Extra Cellular Enzymes Contribute to Their Abundance
}

\author{
Abdul Latif Khan ${ }^{1, *}$, Sajjad Asaf ${ }^{1}{ }^{(D)}$, Raeid M. M. Abed ${ }^{2}$, Yen Ning Chai ${ }^{3}$, \\ Ahmed N. Al-Rawahi ${ }^{1}$, Tapan Kumar Mohanta ${ }^{1}$, Ahmed Al-Rawahi ${ }^{1}$, Daniel P. Schachtman ${ }^{3}$ \\ and Ahmed Al-Harrasi ${ }^{1, *}$ \\ 1 Natural and Medical Sciences Research Centre, University of Nizwa, Nizwa 616, Sultanate of Oman; \\ sajadasif2000@gmail.com (S.A.); ahmed.alrawahi@unizwa.edu.om (A.N.A.-R.); \\ nostoc.tapan@gmail.com (T.K.M.); ahmed@unizwa.edu.om (A.A.-R.) \\ 2 Sultan Qaboos University, College of Science, Biology Department, Muscat 123, Sultanate of Oman; \\ rabed@squ.edu.om \\ 3 Department of Agronomy and Horticulture and Centre for Plant Science Innovation, University of \\ Nebraska-Lincoln, Lincoln, NE 68588, USA; Yenning_hala@hotmail.com (Y.N.C.); \\ daniel.schachtman@unl.edu (D.P.S.) \\ * Correspondence: latifepm78@yahoo.co.uk (A.L.K.); aharasi@unizwa.edu.om (A.A.-H.)
}

Received: 25 November 2019; Accepted: 1 February 2020; Published: 5 February 2020

\begin{abstract}
Revealing the unexplored rhizosphere microbiome of plants in arid environments can help in understanding their interactions between microbial communities and plants during harsh growth conditions. Here, we report the first investigation of rhizospheric fungal and bacterial communities of Adenium obesum, Aloe dhufarensis and Cleome austroarabica using next-generation sequencing approaches. A. obesum and A. dhufarensis grows in dry tropical and C. austroarabica in arid conditions of Arabian Peninsula. The results indicated the presence of 121 fungal and 3662 bacterial operational taxonomic units (OTUs) whilst microbial diversity was significantly high in the rhizosphere of A. obesum and A. dhufarensis and low in C. austroarabica. Among fungal phyla, Ascomycota and Basidiomycota were abundantly associated within rhizospheres of all three plants. However, Mucoromycota was only present in the rhizospheres of $A$. obesum and $A$. dhufarensis, suggesting a variation in fungal niche on the basis of host and soil types. In case of bacterial communities, Actinobacteria, Proteobacteria, Bacteroidetes, Planctomycetes, Acidobacteria, and Verrucomicrobia were predominant microbial phyla. These results demonstrated varying abundances of microbial structure across different hosts and locations in arid environments. Rhizosphere's extracellular enzymes analysis revealed varying quantities, where, glucosidase, cellulase, esterase, and 1-aminocyclopropane-1-carboxylate deaminase were significantly higher in the rhizosphere of $A$. dhufarensis, while phosphatase and indole-acetic acid were highest in the rhizosphere of $A$. obesum. In conclusion, current findings usher for the first time the core microbial communities in the rhizospheric regions of three arid plants that vary greatly with location, host and soil conditions, and suggest the presence of extracellular enzymes could help in maintaining plant growth during the harsh environmental conditions.
\end{abstract}

Keywords: arid land; medicinal plants; microbiome; diversity; metagenomics; extra cellular enzymes

\section{Introduction}

The arid or semi-arid land covers almost $26 \%$ of the earth's ecosystems, where life is constrained and often confronted with extremely low water and high temperature. The vegetation is either succulent (accumulating water) or non-succulent perennial hard plants. Both are true xerophytes and 
are well adapted to the low water conditions [1]. However, in such harsh climatic conditions, endemic micro-symbionts are of great importance for plant survival [2]. Understanding the role of microbial communities and their association with plants during their growth, development, and extreme conditions in arid environments are of considerable interest to ecologists [3-5]. The microorganisms that are predominantly present in the rhizosphere have been shown to play a role in the transport of mineral nutrients, secretion of secondary metabolites, and mitigation of abiotic and biotic stresses [6-10]. During microbial association with the host plants, bacteria and fungi produce various extracellular enzymes that convert the macromolecules into transportable simpler products that can be distributed throughout the plant cells [11-13]. In addition to the initiation of the host-symbiosis process, some of these exozymes hinder the plant pathogenic infections and boost abiotic stress tolerance [14,15]. The plant, on the other hand, facilitates a suitable niche for distinct microbes to grow and reproduce while mutually sharing beneficial exudates and nutrients [16,17]. Such interactions between the microbial communities and medicinal plants have been minimally investigated, particularly in arid ecosystems [5]. Previous studies [18-23] have evaluated the microbiome, especially the bacterial communities from arid soil; however, no studies have been performed on the rhizosphere microbiomes of arid plants.

Despite the importance of the plant life in the arid environments, little is known about their associated endemic microflora [17]. Recently, some studies have been performed on the rhizospheric bacterial microbiomes of plants growing in the arid land ecosystems [24-27]. The analyses of microbiomes of various cultivated plants, including Agave species, Zea mays, Phaseolus vulgaris, Ainsliaea henryi Diels, Dioscorea opposita, Potentilla discolor Bge, Stellera chamaejasme L., Ophiopogon japonicus (Thunb) Ker-Gawl., Juncus effusus L. var. decipiens Buchen., and Rhizoma arisaematis [28,29] showed remarkably high and diverse rhizosphere colonization with Actinobacteria [30]. In addition, some of the recent studies have elucidated the rhizosphere communities of Rehmannia glutinosa [31], Rumex patientia [32], Polygonum cuspidatum [33], Aloe vera [34], Rhododendron arboretum [35], and Thymus zygis [36]. These studies have been restricted to the bacterial communities and did not include fungi, and a few studies used high-throughput next-generation sequencing. However, the importance of understanding the microbiome composition of wild plants growing in the arid environments has at least been demonstrated till now.

In the present study, we have investigated the microbiomes of three plants (A. dhufarensis, C. austroarabica, and $A$. obesum) collected from different areas of the arid land that have previously not been explored. A. obesum and A. dhufarensis are more concentrated in the tropical arid environments, whereas $C$. austroarabica inhabits in extremely arid environments (Figure 1). Moreover, these plants are ecologically and medicinally important too. The plants growing in such an environment often experience a wide array of environmental stresses, including UV irradiation, high heat, drought and strong wind. Rainfall in this region is very limited ( $<80 \mathrm{~mm}$ per annum) and occurs for very short periods. A. dhufarensis, an endemic plant to the Dhofar region in Oman [37], is the least studied but has shown to possess antioxidant potentials [38]. The crushed leaves of $C$. austroarabica produce fragrance. A. obesum is often known as arid rose, and local people use it to treat wounds, venereal diseases, skin diseases, tooth decay, headaches, and muscle pain [39]. These three species are the representative plants in the arid lands of Oman and the Arabian Peninsula and are often exposed to the harsh environmental conditions. However, despite the exposure to the high drought, heat and strong UV conditions, these plants survive for long periods of time. Herein, we investigated for the first time the fungal and bacterial communities associated with the rhizosphere of these three plants species. Comparative studies across the microbiomes allowed us to explore the major and prominent microbial players in the arid plant life. 

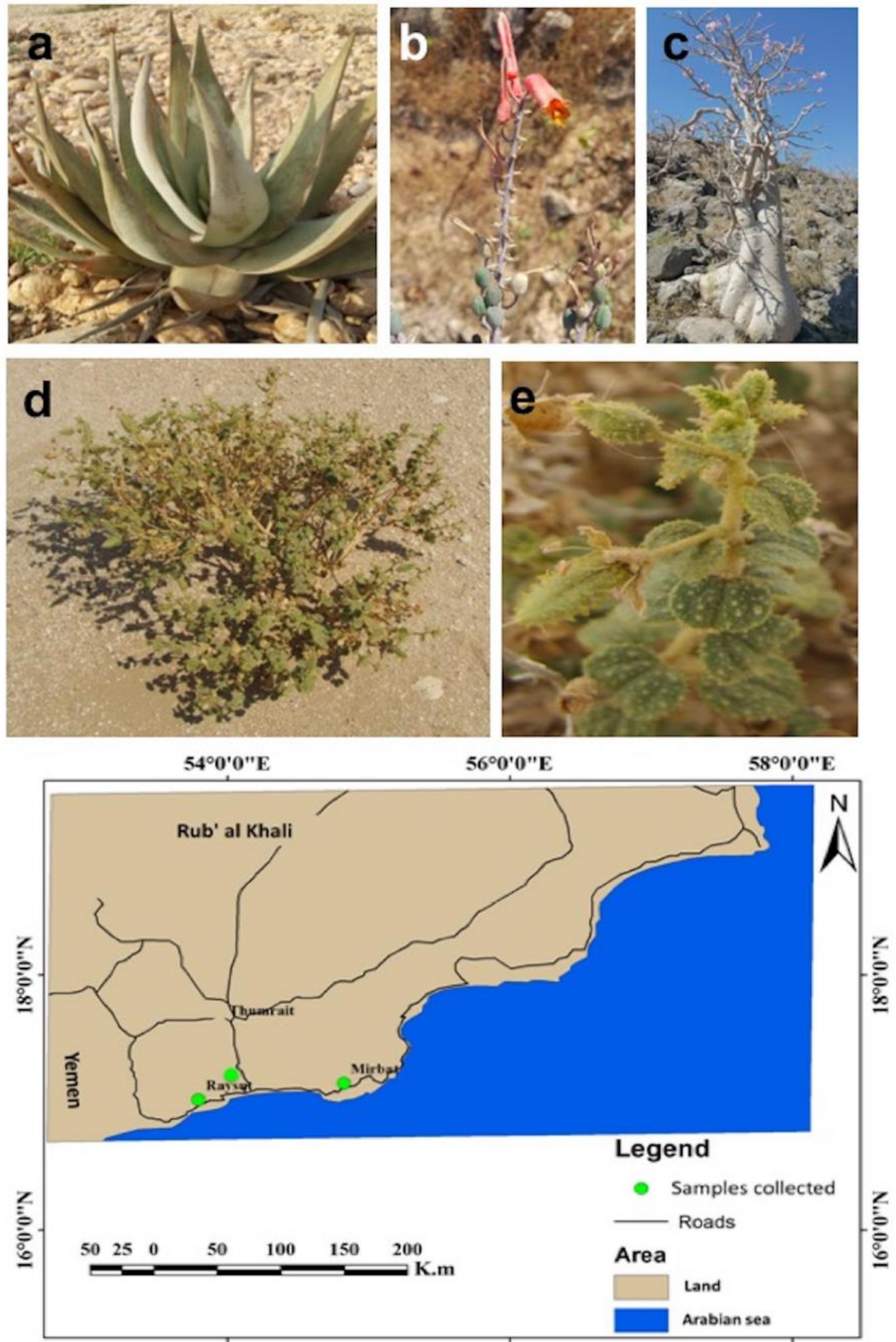

$54^{\circ} 0^{\prime} 0^{\prime \prime} \mathrm{E}$

$56^{\circ} 0^{\prime} 0 " \mathrm{E}$ $58^{\circ} 0^{\prime} 0 "$ E

Figure 1. Plant habitats and their location. (a) A. dhufarensis growing wildly and (b) its flowering part; (c) A. obesum plant and (d,e) C. austroarabica habitat and phyllosphere part. All rhizosphere samples were collected from three different locations. The map for sample collection was made in ArcGIS v9.3.1 (Redlands, CA, USA; http://www.esri.com/software/arcgis/eval-help/arcgis-931). 


\section{Methods}

\subsection{Study Site}

The soil samples from the rhizosphere of A. obesum ( $\left.\mathrm{AO} ; 17^{\circ} 01^{\prime} 11^{\prime \prime} \mathrm{N} 54^{\circ} 08^{\prime} 23^{\prime \prime} \mathrm{E}\right)$, A. dhufarensis

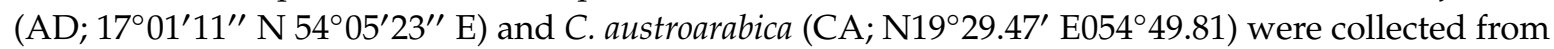
the Dhofar region of the Sultanate, Oman during the dry summer season (June 2016). The rhizosphere soils adjacent to the root surface (5 to 60 inches deep) were collected. For each plant species, thirty soil samples of root rhizosphere regions were collected, which were later pooled into three replicates (ten plants in each replicate). The replicates were approximately $500 \mathrm{~m}$ apart from each other. In contrast, each plant species was 30 to $50 \mathrm{~km}$ apart from each other (Figure 1). The climate of the area is dry and predominant features of dry tropical to arid land weather conditions are prevailing. To understand the soil physical and chemical properties, detailed soil chemical analysis was performed according to the method of Adhikari et al. [40].

\subsection{DNA Extraction and MiSeq Sequencing}

After pooling the soil samples, the mixtures of each rhizosphere soil from each plant species (100 g, in triplicate) were mixed and subjected to the total DNA extraction using the MoBio Power Soil DNA Extraction Kit. PCR free libraries of each DNA sample were generated by amplifying the internal transcribed spacer (ITS2 and ITS4) and 16S rRNA (V3-V4) for fungal and bacterial communities, respectively. For $16 \mathrm{~S}$ rRNA, peptide nucleic acid (PNA) clamps were used to reduce the mitochondrial and chloroplast contamination. A paired-end sequencing approach of $250 \mathrm{bp}$ was conducted on an Illumina MiSeq instrument (Illumina Inc., San Diego, CA, USA) operating with v2 chemistry (User Guide Part \# 15,027,617 Rev. L). All quality reads related to the study are available at NCBI under BioProject PRJNA337739, 16S Accessions (KDUM00000000, KDUL00000000, KDUK00000000), and ITS Accessions (KDUJ00000000, KDUI00000000, KDUH00000000).

\subsection{Data Processing and Analyses}

The raw sequence reads were merged, trimmed, filtered, and clustered at $97 \%$ identity for fungal and bacterial sequences using the UPARSE pipeline [41]. Taxonomies were assigned to each bacterial OTU using the RDP Naïve Bayesian Classifier [42] trained on the Greengenes database [43]. Fungal taxonomy assignment was performed with the Naïve Bayer classifier trained on the UNITE reference database [42]. The OTUs whose taxonomic classifications did not match to their expected kingdoms (bacteria and fungi) were removed. Each sample was rarefied to 96,961 and 26,999 for bacterial and fungal reads, respectively, prior to alpha and beta diversity analysis. For the alpha diversity, the Chao1 index and Shannon diversity were used to determine the species richness and diversity in the samples (Figure 2). The plots for Chao1 index and Shannon diversity were generated with Microbiome Analyst [44]. For beta diversity, canonical analysis of principal coordinate (CAP) was performed based on Bray-Curtis and both weighted and unweighted UniFrac distances using the Vegan package in $R$ (Version 1.0.44) [45]. Canonical correlation analysis (CCA) was employed to examine the relationship between the microbes and measured enzyme activities [46]. 

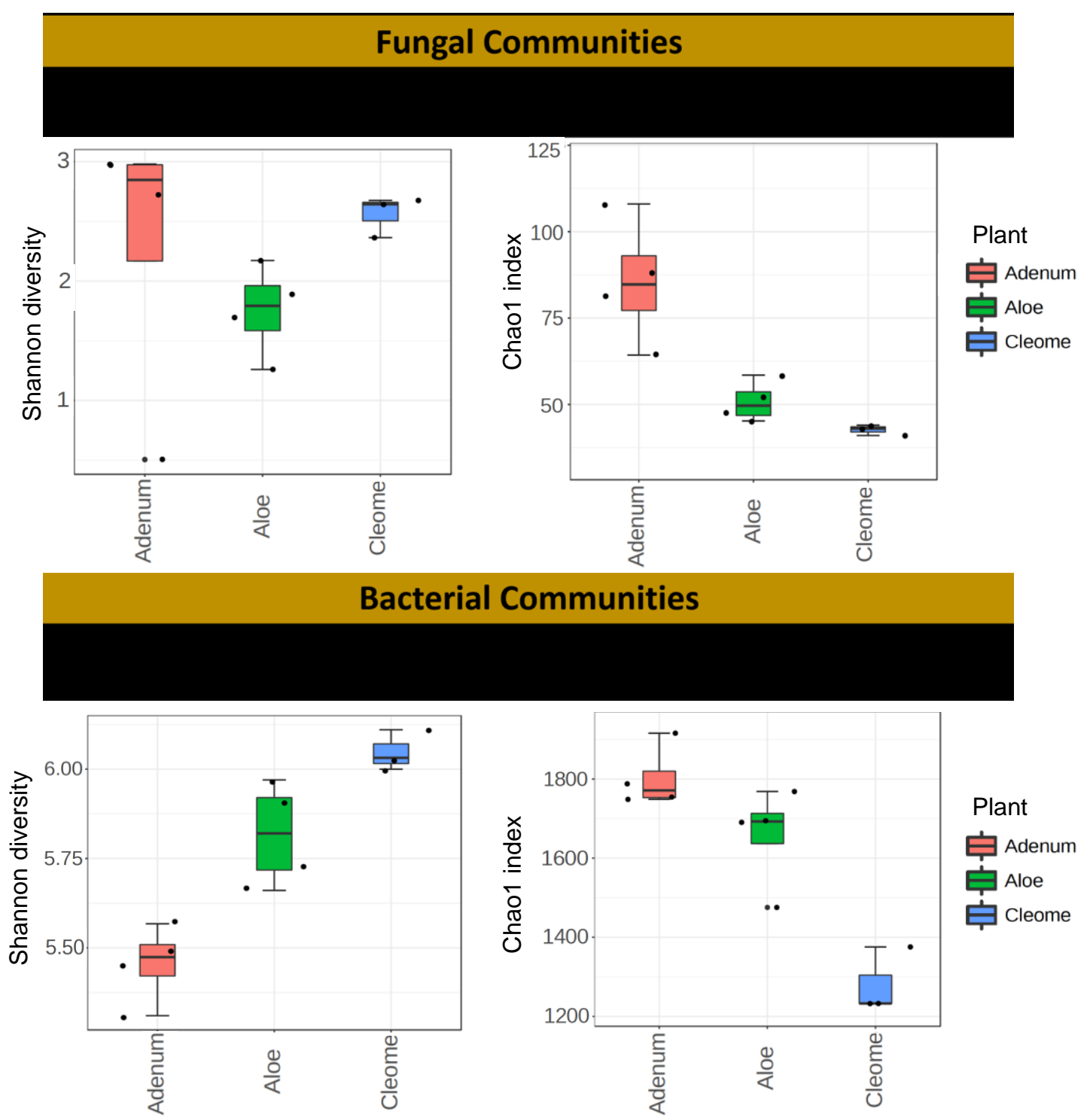

Figure 2. Distribution of operational taxonomic units (OTUs) for fungal and bacterial communities and Chao-1 of each replica from data generated through MiSeq sequencing (16S and ITS) of the rhizosphere samples from $A$. dhufarensis, A. obesum and C. austroarabica. Nonmetric multidimensional scaling (NMDS) plots for Bray-Curtis distances of fungal and bacterial communities associated with the three plant species. Shannon index is presented in the left and Chao1 is presented in the right side of the figure.

\subsection{Microbial Products in Rhizosphere Soils}

To estimate the extracellular enzymes (glucosidase, phosphatase, esterase, and cellulase), the method reported by Marx et al. [47] and Khan et al., [15] was used with minor modifications. Briefly, all chemical reagents were obtained from Sigma-Aldrich Co. Ltd. (Munich, Germany). A $10 \mathrm{~mL}$ aliquot of a $10 \mathrm{mM}$ stock solution of each 4-methylumbelliferone (MUB) substrate was prepared. The assay procedures for all the substrates were the same. A 7-MUB standard was used for the study. A stock solution of MUB $(10 \mathrm{mM})$ was prepared in methanol $(0.1762 \mathrm{~g}$ of 4-methylumbelliferone in $100 \mathrm{~mL})$ that was subsequently diluted to $1 \mu \mathrm{M}$ in sodium acetate ( $\mathrm{pH}$ 5.2) buffer. The soil samples were analyzed for exozymes as described by Marx et al. (2001) [47] using a fluorescence spectrophotometer (Shimadzo, Tokyo, Japan). The methodology of Honma and Shimomura was applied for ACC deaminase activity with some modifications as described by Shaharoona et al. [48], and the amount of $\alpha$-ketobutyrate 
produced from the hydrolysis of ACC was measured (Supplementary methods). The quantification of indole-3-acetic acid in the soil sample was performed as described by Khan et al. (2016) [15].

\subsection{Statistical Analysis}

At least three replicate samples were analyzed during this study. The data for the enzyme study are presented as the mean \pm standard error of the mean (SEM). The significant differences were studied using ANOVA (one-way analysis of variance) approach. The significant differences were considered significant at $p<0.05$ and were calculated by GraphPad Prism Version 6.01 (GraphPad Software, San Diego, CA, USA). Duncan's multiple range test at $p<0.05$ (SAS 9.1, Cary, NC, USA) was used to compare the mean values. For the multivariate analyses, statistical analysis was performed using permutational multivariate analysis of variance (PERMANOVA) with 999 permutations.

\section{Results}

\subsection{Soil Variations among Three RHIZOSPHERES}

The soil analysis of the three rhizosphere regions of $A$. dhufarensis, A. obesum and C. austroarabica showed variability among two locations (dry tropical to arid). The two plants from arid land (A. obesum and $A$. dhufarensis) showed a similar pattern $(p<0.05$; insignificant statistically) of distribution of various physical (temperature, moisture content, clay, sand, silt, gravel, bulk density, organic matter, and texture) and chemical (electrical conductivity, $\mathrm{pH}$, nitrates, and phosphorus) soil quality parameters as compared to $C$. austroarabica suggesting an extreme growth conditions (Table 1).

Table 1. Physio-Chemical attributes of soils collected from the different rhizospheres of three plants.

\begin{tabular}{llll}
\hline \multicolumn{1}{c}{ Parameters } & A. obesum & A. dhufarensis & C. austroarabica \\
\hline Temperature $\left({ }^{\circ} \mathrm{C}\right)$ & 37 & 37.3 & 41.3 \\
Moisture contents $(\%)$ & 18.7 & 19 & 10.1 \\
Clay $(\%)$ & $8.1 \pm 1.01 \mathrm{a}$ & $6.6 \pm 0.9 \mathrm{~b}$ & $2.4 \pm 0.4 \mathrm{c}$ \\
Sand $(\%)$ & $34 \pm 2.1 \mathrm{c}$ & $38.5 \pm 2.1 \mathrm{a}$ & $78.3 \pm 0.6 \mathrm{a}$ \\
Silt $(\%)$ & $19.6 \pm 1.01 \mathrm{a}$ & $17.6 \pm 0.8 \mathrm{a}$ & $11.8 . \pm 1.5 \mathrm{~b}$ \\
Gravel $(\%)$ & $38.3 \pm 1.01 \mathrm{a}$ & $37.3 \pm 0.8 \mathrm{a}$ & $2.5 . \pm 0.3 \mathrm{~b}$ \\
Bulk density $(\%)$ & $4.7 \pm 0.8 \mathrm{a}$ & $3.9 \pm 0.7 \mathrm{a}$ & $1.1 \pm 0.4 \mathrm{~b}$ \\
Organic matter $(\%)$ & $4.2 \pm 0.6 \mathrm{a}$ & $5.2 \pm 0.4 \mathrm{a}$ & $0.9 \pm 0.1 \mathrm{~b}$ \\
Texture & sandy loam & sandy loam & sandy \\
EC $\left(\mathrm{dSm}{ }^{-1}\right)$ & $31 \pm 1.4 \mathrm{a}$ & $30 \pm 1.9 \mathrm{a}$ & $2.1 \pm 0.7 \mathrm{~b}$ \\
pH & $7.3 \pm 0.8 \mathrm{a}$ & $7.6 \pm 0.4 \mathrm{a}$ & $6.8 \pm 0.4 \mathrm{~b}$ \\
Nitrates $(\mathrm{mg} / \mathrm{kg})$ & $3.9 \pm 0.4 \mathrm{a}$ & $3.4 \pm 0.7 \mathrm{a}$ & $0.8 \pm 0.2 \mathrm{~b}$ \\
Phosphorus $(\mathrm{mg} / \mathrm{kg})$ & $2.1 \pm 0.3 \mathrm{a}$ & $2.2 \pm 0.4 \mathrm{a}$ & $0.4 \pm 0.1 \mathrm{~b}$ \\
\hline
\end{tabular}

Values in each column are the mean of five replications and presented with standard error. The different letter in each row showed that the values are significantly different $(p<0.05)$.

\subsection{Microbial Diversity in the Rhizosphere of the Three Plants}

A total of $361.4 \mathrm{Mb}$ and $0.786 \mathrm{~Gb}$ of high-quality read data (Q20\% 98.64; $\mathrm{Q} 30 \%$ 94.31) were generated for fungal and bacterial communities, respectively (Table S1). The mean read count was $110,712 \pm 13.87$ and 194,927 \pm 11.32 for ITS and 16S, respectively (Table 2; Figure S1). In the case of fungi, the highest average read count was obtained in A. dhufarensis $(13,0150 \pm 38.81)$. A total average of 102,062 \pm 16.31 and 99,923 \pm 18.89 fungal reads were generated from A. obesum and C. austroarabica, respectively. In the bacterial community analysis, the highest average read count was identified in C. austroarabica $(200,875 \pm 14.73)$, followed by A. obesum $(197,910 \pm 9.01)$. A. dhufarensis had the lowest average read count $(185,997 \pm 16.76$; Table 2$)$. 
Table 2. MiSeq sequencing and bacterial diversity estimators of the rhizosphere of three medicinally important plants.

\begin{tabular}{cccccc}
\hline Plant & Replicate & Total No. of Sequences & No. of OTUs * & Chao1 & Shannon \\
\hline \multirow{3}{*}{ A. dhufarensis } & 1 & Fungal communities & & & \\
& 2 & 69673 & 131 & 58.5 & 1.9 \\
A. obesum & 3 & 48156 & 104 & 47.3 & 1.7 \\
& 1 & 26999 & 85 & 45.2 & 2.2 \\
C. austroarabica & 2 & 65158 & 176 & 88.0 & 2.7 \\
& 3 & 51709 & 196 & 81.5 & 3.0 \\
& 1 & 78490 & 229 & 108.0 & 3.0 \\
A. dhufarensis & 2 & 42156 & 50 & 43 & 2.4 \\
& 3 & 39003 & 49 & 44 & 2.6 \\
A. obesum & 1 & 33497 & 63 & 41 & 2.7 \\
& 2 & Bacterial communities & & & \\
C. austroarabica & 1 & 150605 & 3966 & 1768.5 & 5.7 \\
& 2 & 133210 & 3241 & 1690.5 & 5.7 \\
& 1 & 126210 & 4834 & 1694.7 & 6.0 \\
& 2 & 206761 & 3622 & 1754.2 & 5.5 \\
& 3 & 176014 & 3296 & 1748.8 & 5.3 \\
\hline
\end{tabular}

* Operational taxonomic unit at $3 \%$ sequence dissimilarity based on equal subsets of sequences for all samples,

Chao1 is based on rare OTUs in a given sample and Shannon abundance-based coverage.

The number of OTUs calculated using the subsets with the same number of sequences for the three plant samples ranged from 50 to 229 for fungal communities and from 2812 to 4834 for bacterial communities (Table 1; Table S2). In overall comparison among microbial communities, the current result suggests a higher abundance of bacterial communities than fungal communities. Fungal OTU richness and diversity were significantly highest $(p<0.076)$ in A. obesum $(201 \pm 1.3)$ and lowest in C. austroarabica ( $54 \pm 1.9$; Figure 2; Table 2). This was further validated with Chao1 analysis showing rare OTUs in the three replicates of each sample (Figure 2; Table 2). The abundance-based coverage showed a significantly higher $(p<0.001)$ fungal diversity in the rhizosphere of A. obesum than the other two plants. In the case of bacterial communities, the significantly highest $(p<0.0014)$ number of OTUs was obtained from $A$. dhufarensis $(4014 \pm 33.6)$ and the lowest number of OTUs was obtained from C. austroarabica ( $3427 \pm 5.3)$ (Table 2). Similarly, Chao 1 was significantly higher $(p<0.0034 ; 1764 \pm 37.2)$ in A. obesum compared to A. dhufarensis (1718 \pm 6.2$)$ and C. austroarabica (1280 \pm 8.6 ; Table 2$)$. This shows the presence of higher abundance of individual species in A. obesum that reflects the singleton of species richness in fungi and bacteria. In the case of Shannon diversity indices, there was a non-significant difference in the fungal diversity of $C$. austroarabica and A. obesum, and the Shannon diversity index was significantly lower in $A$. dhufarensis. In contrast, the bacterial population was significantly higher $(p<0.019 ; 5.8 \pm 3.1)$ in C. austroarabica than A. obesum $(5.4 \pm 0.7)$ and C. austroarabica (6.3 \pm 2.6 ; Table 2; Table S3).

The abundance of $16 \mathrm{~S}$ sequences with regards to the location 1 (dry tropical) and 2 (arid) was analyzed using Bray-Curtis, weighted, and unweighted principal component analysis. The Bray-Curtis analysis of fungal communities showed that $A$. dhufarensis and C. austroarabica showed their presence in both the locations. However, A. obesum showed its partial presence in both the locations (Figure 3). Similarly, for bacterial communities, A. dhufarensis was found in both locations, whereas $C$. austroarabica was found to a lesser extent (Figure 3; Figure S2). 

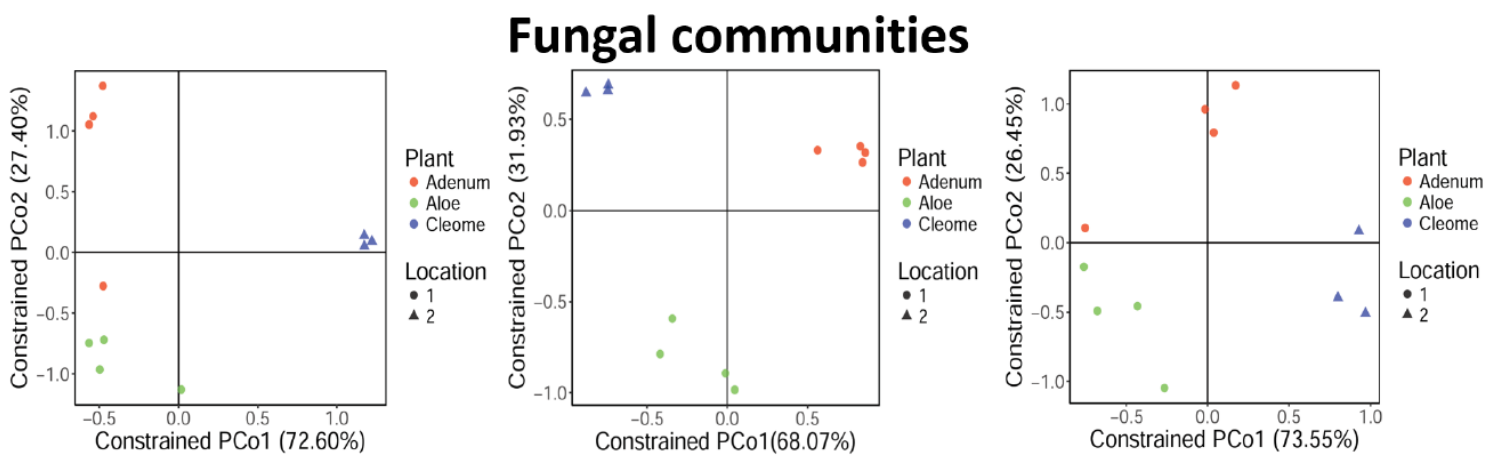

Bacterial communities
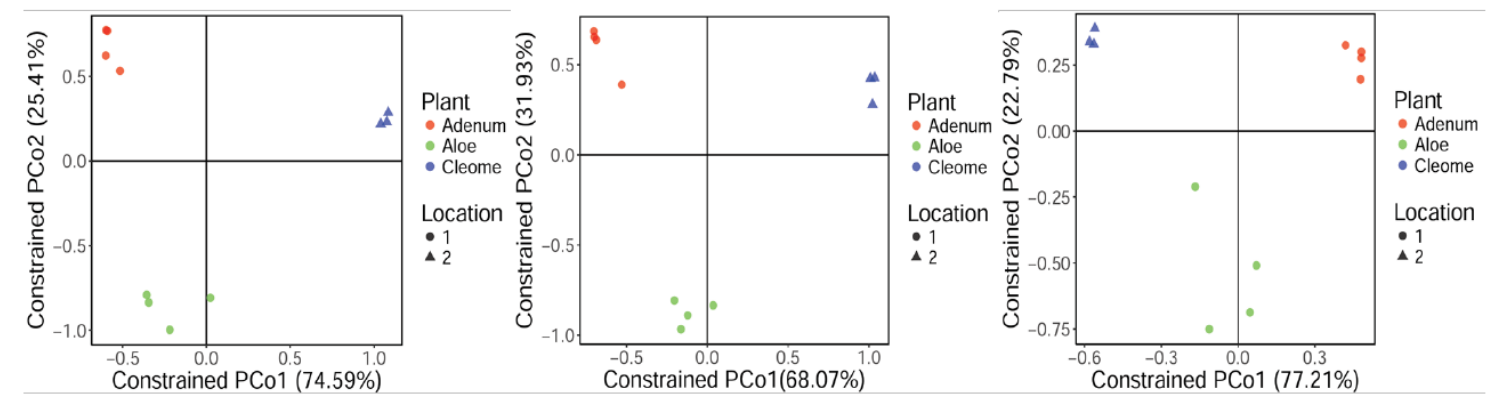

Bray-curtis

Unweighted

Weighted

Figure 3. Constrained analysis of principal coordinates (CAP) plots for the fungal and bacterial communities in the rhizosphere of A. dhufarensis, A. obesum, and C. austroarabica. The communities were constrained by geographical location ( 1 -sub-tropical arid conditions and 2 - absolute arid conditions). The CAP analysis was performed on Bray-Curtis, weighted and unweighted distances. The significance of the CAP models was evaluated using ANOVA with 999 permutations.

\subsection{Rhizosphere Fungal Diversity}

Unidentified fungal sequences constituted $\sim 9 \%$ to $42.5 \%$ of the total sequences of the three plants. These unidentified sequences were significantly higher $(68.46 \% ; p<0.0001)$ in $C$. austroarabica than in the other two plants. Two major phyla, Ascomycota and Basidiomycota, were detected in all of the studied plant species (Figure 4). However, Mucoromycota was only present in the A. obesum and A. dhufarensis rhizospheres, suggesting a variation in the fungal niche. In addition, C. austroarabica is from an extremely arid environment (location 2), and the presence of Glomeromycota and Mortirellomycota is an interesting feature of its rhizosphere. Furthermore, the abundance of Basidiomycota appreciably reduced and Glomeromycota increased in C. austroarabica compared to A. obesum and A. dhufarensis, indicating an influence of location-specific changes in the microbial population. Ascomycota was the most predominant $(34.97 \%)$ phylum in the rhizosphere samples of the three plants. Its relative abundance was significantly highest in C. austroarabica $(72.90 \% ; p<0.001)$ and lowest in A. dhufarensis. Basidiomycota was the second most dominant phylum and was found to be significantly higher in A. dhufarensis (14.53\%) than in A. obesum (13.8\%) and C. austroarabica (3.1\%) (Figure 4; Table S4). 

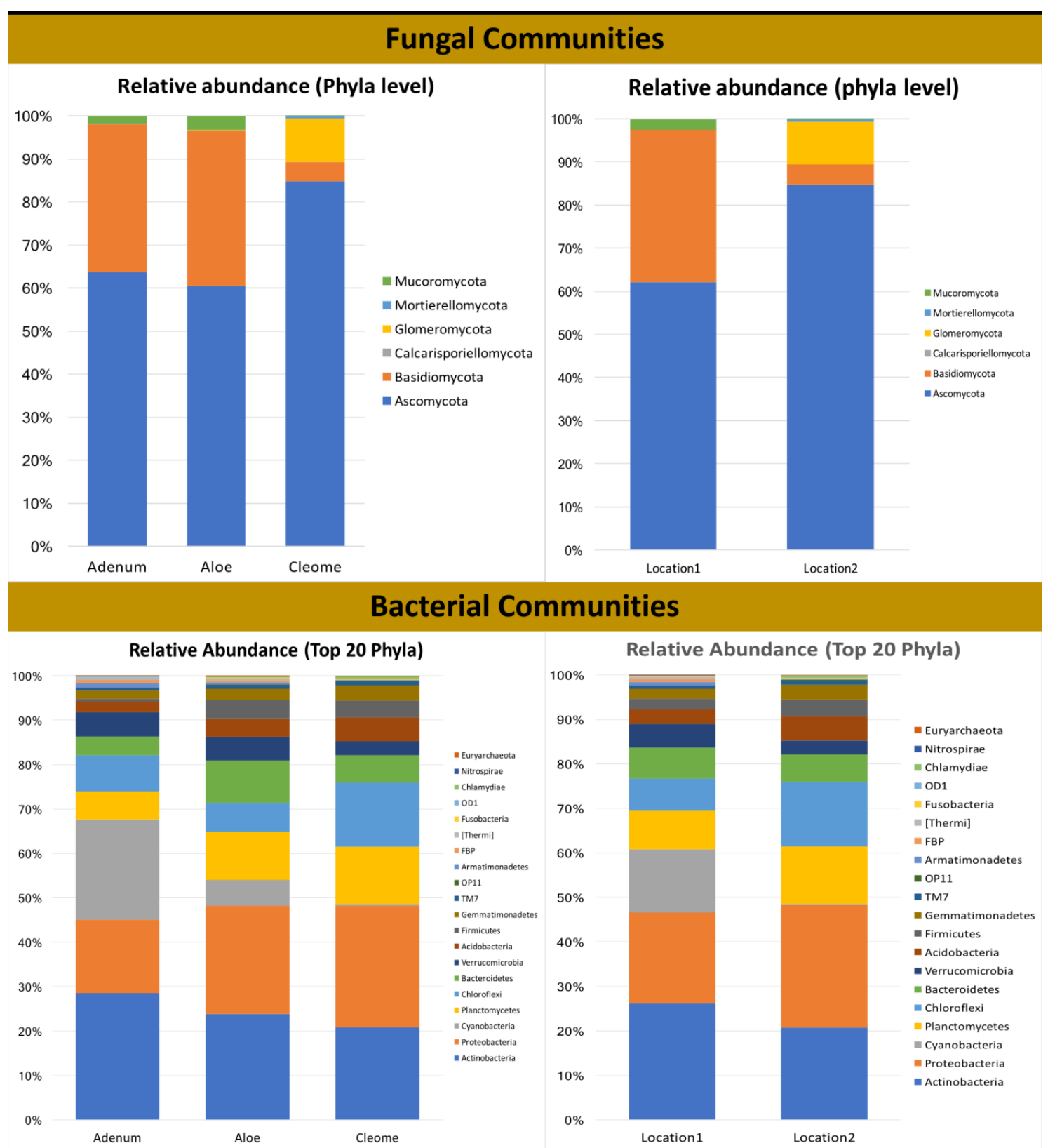

Figure 4. Relative abundances and shared core OTUs of fungal and bacterial phyla and the genera found in the rhizosphere of A. dhufarensis, A. obesum and C. austroarabica.

Different genera were encountered in the three-plant species, with Acremonium as the most abundant in A. obesum (9.17\%) and A. dhufarensis (4.92\%) compared to C. austroarabica. Ascotricha was only abundant in A. dhufarensis (14.77\%). Similarly, Ceratobasidium $(\sim 6.7 \%)$ was highly abundant in A. obesum (13.93\%) and A. dhufarensis (12.95\%). In contrast, Corynascus (5.63\%) was abundant in C. austroarabica. Aspergillus, Paecilomyces, Preussia, Alternaria, and Teratosphaeria were also among the abundant genera (Figure 4). Cluster analysis with regard to sample collection (site 1 and site 2) showed that $A$. dhufarensis and C. austroarabica grouped together for their abundance in fungal communities (Figure 4). Rhizopus, Orbiliaceae, Hypocreales, and Fusarium were only specific to A. dhufarensis, whereas Ascomycota, Chaetomiaceae, Eurotiomycetes, and Thanatephorus were abundant in both the locations (Figures 4 and 5). However, Pleosporales was specific to the location 2 and only found in A. obesum. The location-specific (location 1 and location 2) diversity was studied for the fungal communities using Bray-Curtis and unweighted and weighted analyses. The Pco1 for the Bray-Curtis, 
unweighted, and weighted analyses were $72.6 \%, 68.07 \%$, and $73.55 \%$, respectively, whereas Pco 2 for the Bray-Curtis, unweighted, and weighted analysis were $27.4 \%, 31.93 \%$, and 26.45\%, respectively (Figure 3). The weighted study measures the number of species within the population represented by each member of the sample, whereas in the unweighted, all samples were weighted equally.

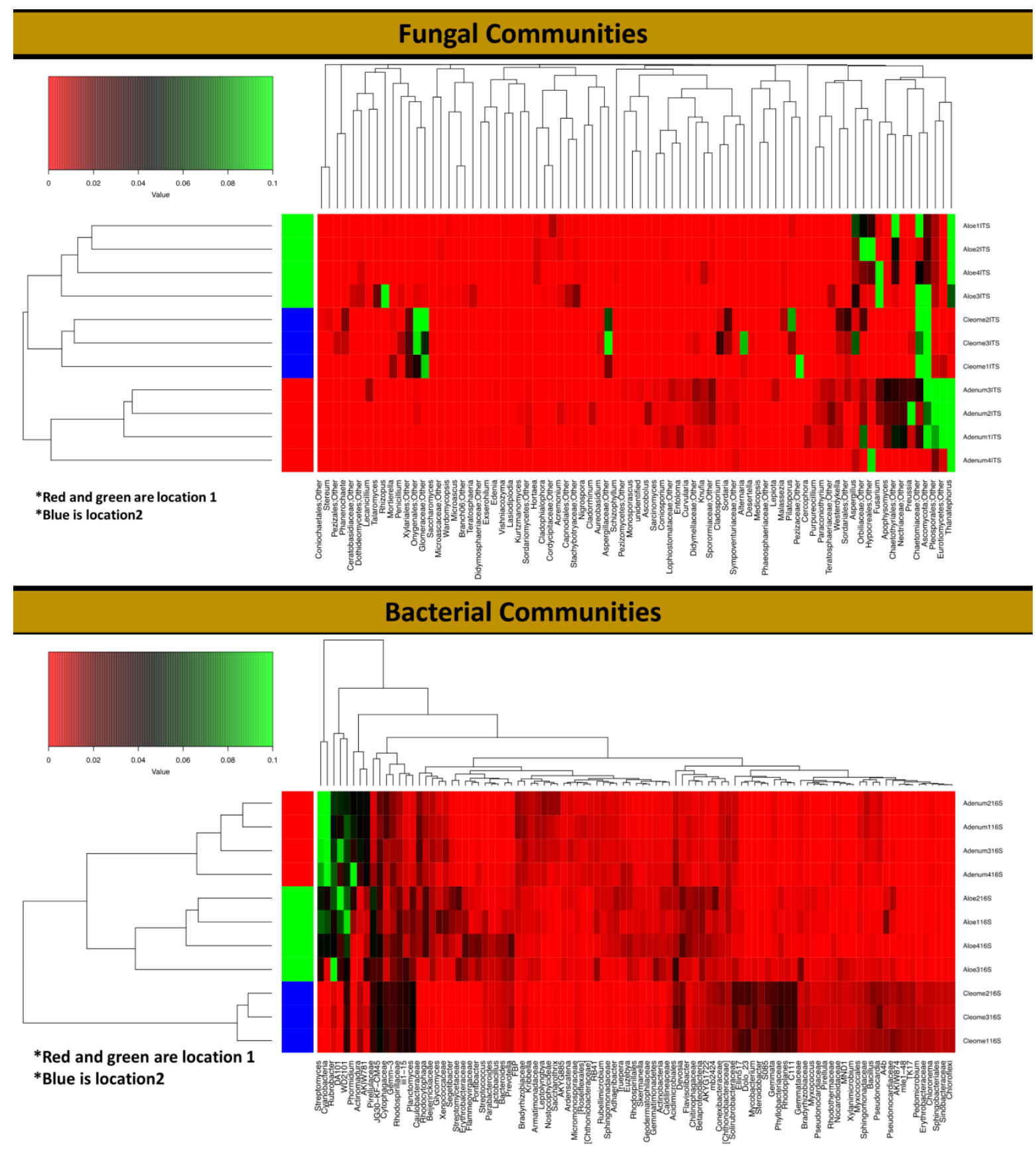

Figure 5. Heat map and dendrogram generated for fungal and bacterial communities in the rhizosphere of A. dhufarensis, A. obesum and C. austroarabica using highly abundant OTUs across all of the samples and their replicates.

\subsection{Rhizosphere Bacterial Diversity}

A total of 32 bacterial phyla were detected, including Actinobacteria (26.43\%), Proteobacteria $(17.55 \%)$, Cyanobacteria $(10.9 \% \%)$, Planctomycetes $(7.57 \%)$, and Verrucomicrobia $(7.68 \%)$. The relative abundance of Actinobacteria (31.21\%; $p<0.0002)$ and Cyanobacteria $(26.88 \% ; p<0.0032)$ was higher 
in A. obesum than A. dhufarensis and C. austroarabica (Figures 4 and 5). Bacteroidetes (12.74\%) were higher in A. dhufarensis, whereas Chloroflexi (10.34\%) and Acidobacteria (5.48\%) were abundant in C. austroarabica (Figure 4; Table S5). In total, 274 different genera were found in all the plants, although 34 of the total sequences could not be assigned to known the genera (Figure 4). Firmicutes were present in A. dhufarensis and C. austroarabica but was absent in A. obesum (Figure 4). Euryarchaeota was found in A. obesum and A. dhufarensis, whereas it was absent in C. austroarabica (Figure 5). Overall, Streptomyces (5.81\%), Actinomadura (1.62\%), Rubrobacter (6.67\%), Ohtaekwangia (1.34\%), Bacteroides $(0.75 \%)$, Sphaerobacter (1.99\%), Gemmatimonas (1.17\%), Pirellula (0.90\%), Planctomyces (1.54\%), Microvirga $(1.66 \%)$, and Sphingomonas (2.31\%; Figure 4) were the most abundant across the three medicinal plants. Across the rhizosphere of the three plants, sequences belonging to the genera Streptomyces, Rubrobacter, Spartobacteria, and Sphingomonas were significantly abundant in A. dhufarensis and A. obesum compared to C. austroarabica. However, the genera Ilumatobacter, Mesorhizobium, Ohtaekwangia, Solirubrobacter, Pirellula, Planctomyces, and Sphaerobacter were abundantly distributed in C. austroarabica. A location-specific study of bacterial communities revealed quite universal abundance, except for a few cases. In location 1, Streptomyces species were found in A. obesum, whereas Rubrobacter was found in A. obesum and A. dhufarensis (Figure 5; Table S6). In location 2, the abundance level of Proteobacteria was higher than the location 1.

\subsection{Exozymes, ACC Deaminase and IAA in the Rhizosphere}

The results showed varying activities of the extracellular enzymes among the three studied plant species. The activities of glucosidase, cellulase, and esterase were significantly higher $(p<0.0001)$ in the rhizosphere of $A$. dhufarensis than in the rhizosphere of C. austroarabica and A. obesum (Table 3). In contrast, phosphatase activity was significantly higher $(p<0.001)$ in $A$. obesum than the other plant rhizospheres. The ACC deaminase activity was significantly $(p<0.0002)$ higher $(\sim$ two-fold $)$ in $A$. dhufarensis than in other species. However, low activity of ACC deaminase was observed in C. austroarabica (Table 3). The three rhizosphere soil samples from the plants showed varying concentrations of indole-3-acetic acid (IAA) content. Among the plants, the rhizosphere of A. obesum showed significantly higher $(p<0.0029)$ IAA content compared to the other two species (Table 3). C. austroarabica showed the lowest amount of IAA in the rhizosphere soil. The canonical correlation analysis (CCA) with regard to the presence of enzymes cellulase, glucosidase, and phosphatase was conducted to understand the correlation for the diversity of fungal and bacterial communities in A. obesum, A. dhufarensis, and C. austroarabica (Figure 6). In the case of fungal communities, CCA1 was 0.9218 and CCA2 was 0.3330 , whereas in the case of bacterial communities, CCA1 was 0.7380 and CCA2 was 0.2401 . A positive correlation was observed in C. austroarabica for the phosphatase enzyme for bacteria and fungi. A positive correlation was recorded for cellulase activity in A. obesum for bacteria and fungi, whereas glucosidase had a negative correlation for both bacteria and fungi (Figure 6). 
Table 3. Exozymes and essential metabolites of the rhizosphere soil of the three plants.

\begin{tabular}{|c|c|c|c|c|c|c|}
\hline \multirow[t]{2}{*}{ Assays } & \multicolumn{3}{|c|}{ Enzyme Properties } & \multicolumn{3}{|c|}{ Plant Species } \\
\hline & Function & Substrate & Conc. $(\mu \mathrm{M})$ & A. dhufarensis & A. obesum & C. austroarabica \\
\hline $\begin{array}{c}\text { Cellulase }(1,4-\beta \\
\text {-cellobiosidase; }\left(\mu \mathrm{mol} \mathrm{h}{ }^{-1} \mathrm{~g}^{-1}\right)\end{array}$ & $\begin{array}{l}\text { Cellulose to } \\
\text { disaccharide }\end{array}$ & 4-MUB-phosphate 3.1.3.1 & $10-100$ & $157.1 \pm 1.2^{\mathrm{a}}$ & $134.2 \pm 1.0^{\mathrm{b}}$ & $105.8 \pm 1.0^{c}$ \\
\hline Phosphatase $\left(\mu \mathrm{mol} \mathrm{h}{ }^{-1} \mathrm{~g}^{-1}\right)$ & $\begin{array}{l}\text { Phosphomonoesters } \\
\text { to phosphate }\end{array}$ & $\begin{array}{l}\text { 4-MUB- } \beta \text {-D-cellobioside } \\
\text { 3.2.1.91 }\end{array}$ & $10-100$ & $9.6 \pm 0.2^{b}$ & $11.4 \pm 0.9^{a}$ & $5.2 \pm 0.6^{c}$ \\
\hline $\begin{array}{l}\text { Glucosidase }(\beta-1,4 \text {-glucosidase; } \\
\left(\mu \mathrm{mol} \mathrm{h}{ }^{-1} \mathrm{~g}^{-1}\right)\end{array}$ & Cellulose to glucose & $\begin{array}{l}\text { 4-MUB- } \beta \text {-D-glucopyranoside } \\
\text { 3.2.1.21 }\end{array}$ & $10-100$ & $16.9 \pm 0.8^{\mathrm{a}}$ & $13.8 \pm 0.4^{b}$ & $5.5 \pm 0.7^{\mathrm{c}}$ \\
\hline Esterase $\left(\mu \mathrm{mol} \mathrm{h}^{-1} \mathrm{~g}^{-1}\right)$ & $\begin{array}{l}\text { Acid to alcohol } \\
\text { (hydrolyses) }\end{array}$ & $\begin{array}{l}\text { 4-Methylumbelliferyl } \\
\text { butyrate }\end{array}$ & $10-100$ & $152.0 \pm 1.01^{\mathrm{a}}$ & $131.1 \pm 2.0^{\mathrm{b}}$ & $117.1 \pm 2.7^{\mathrm{c}}$ \\
\hline IAA $(\mu \mathrm{mol} / \mathrm{mL})$ & $\begin{array}{c}\text { Plant root } \\
\text { development }\end{array}$ & - & 100 & $129.5 \pm 2.8^{b}$ & $159.8 \pm 2.9^{a}$ & $122.6 \pm 3.4^{b c}$ \\
\hline $\begin{array}{c}\text { ACC deaminase }(\mathrm{nmol} \\
\left.\alpha \text {-ketobutyrate } \mathrm{mg}^{-1} \mathrm{~h}^{-1}\right)\end{array}$ & $\begin{array}{l}\text { Lowering plant } \\
\text { ethylene levels }\end{array}$ & $\mathrm{ACC}$ & 100 & $181.2 \pm 2.8^{\mathrm{a}}$ & $98.1 \pm 2.8^{b}$ & $39.8 \pm 2.8^{c}$ \\
\hline
\end{tabular}

The different letters in each row for each parameter shows a significant difference ( $p<0.05)$ as evaluated by Duncan's multiple range test (SAS v9.0, CA, USA). Adenium obesum, Aloe dhufarensis and Cleome austroarabica. 


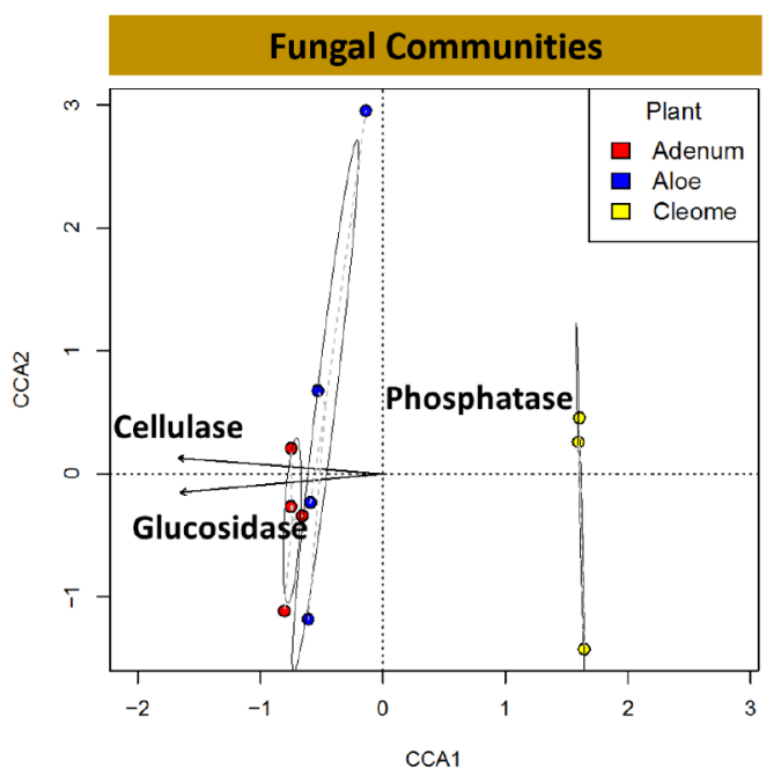

CCA1 $=0.9218 ; C C A 2=0.3330$

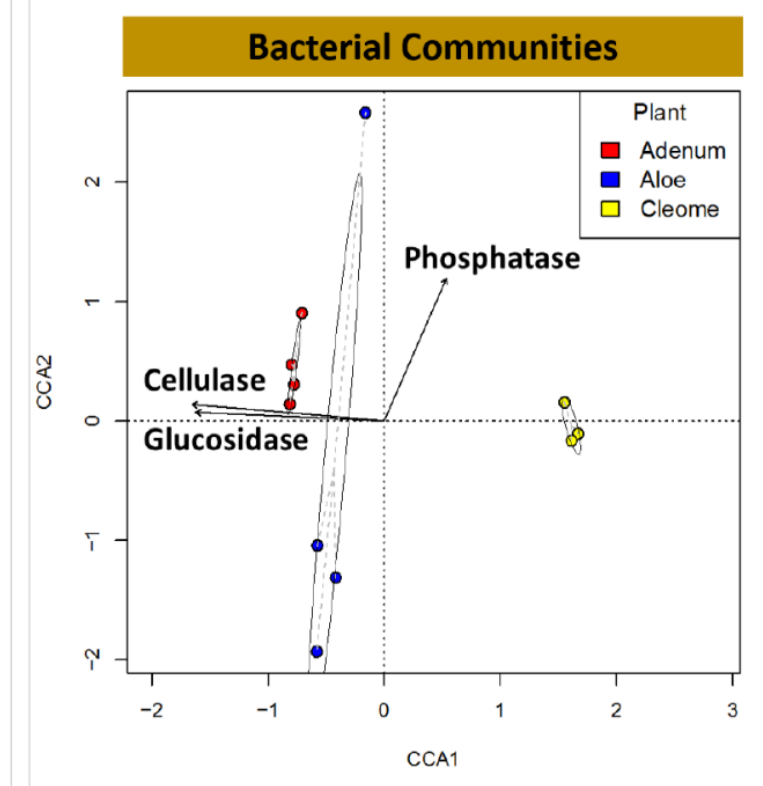

CCA1 $=0.7380 ;$ CCA2 $=0.2401$

Figure 6. Correspondence analysis (CCA) for fungal and bacterial communities in the rhizosphere of A. dhufarensis, A. obesum, and C. austroarabica and their interaction with the abilities to produce extracellular enzymes (phosphatase, cellulase, and glucosidase).

\section{Discussion}

The results showed diverse niche of microorganisms in the rhizosphere of three plant species. This was also evidenced from the soil physical and chemical properties suggesting a complete segregation of the two locations i.e., dry tropical to the complete arid land system. Comparing both types of the rhizosphere from arid plant species could be essential to understand the major microbial associations. Although, the majority of the present insights into the interactions and processes of rhizosphere microbiome have come from studies on model plants such as Arabidopsis thaliana and Medicago truncatula and agricultural or horticultural crops [10,26,49], nonetheless, a reasonable progress has also being made in elucidating the microbial ecology of non-cultivated plant species $[16,17,26]$. Some studies also showed that how microbial associations impact the resource allocation, biodiversity and above-ground interactions with herbivores and their natural enemies [50,51]. Understanding microbial diversity across different soil types and locations of wild plants could also help in future expansion of agricultural activities in broader ecological niches and wastelands.

To some extent, microbial players and their abundances depends not only on the biogeography of the host plant species but also on host genotype, which is still being investigated by comparing microbial communities of the sample plant during varying seasonal conditions [52]. The present study elucidated the fungal and bacterial association of three medicinal plant species that displayed a varying response in the metagenomics data output as well as the number of OTUs. This finding was also validated in the recent studies that demonstrated host-specific characteristics such as a wide variety of morphology [53] and genomics [54,55] could convincingly affect the microbiome structure and diversity $[16,56]$. Although the climatic, soil, and plant growth parameters were quite similar, A. dhufarensis, C. austroarabica and A. obesum possess considerably different features in their growth, morphology, and genetic makeup, resulting in a varying nature of bacterial and fungal communities in the rhizosphere. This substantial difference in the microbial diversity can be attributed to the microsite niche heterogeneity $[57,58]$.

The roots and their exudates can reduce the niche heterogeneity, which in turn affects the diversity and abundance of fungal and/or bacterial communities [7,59]. A. dhufarensis and A. obesum are known 
as sap-producing plants $[37,60]$ in their phyllosphere continuum, which naturally becomes part of the rhizosphere either by root exudation or by wounding through herbivory. C. austroarabica, and is also rich in the essential oils [59]. Such host plant potentials can also result in the distribution and occurrence of certain classes of microbial communities. Therefore, a varying composition of OTUs was observed for the three medicinal plants. A similar conclusion was drawn when root exudates of maize and soybean shown drastic effects in the rhizosphere bacterial community structure and composition [61]. Rasmann and Turlings (2016) [62] recently suggested that the plant kind and its root exudation could influence the mutualistic interaction in the rhizosphere. In addition, the immediate changes in the soil attributes $(\mathrm{pH}$, water, and $\mathrm{C}$ availability) either climatically or by the host itself and it can increase or reduce the abundance of rhizosphere microbiomes [27,50]. In addition, the difference in microbial communities associated with $A$. dhufarensis suggests that the microbiome of a species or cultivar exhibits both specific microbial lineages with host-specific abundance patterns and a conserved core microbiome [57,58].

In addition to the abundance, the distribution of microbial communities also differed across the three plant species. Although Basidiomycota and Ascomycota were abundant phyla, the contribution of unidentified fungi was still high in the three plants. This suggests the presence of novel fungal diversity in rhizosphere that have yet to be described. This report is consistent with previous studies on semi-arid land plants $[27,34,36]$. Corynascus, which has been classified as thermophilic in arid land ecosystems, was abundant in C. austroarabica, suggesting its dominant role in countering climatic perturbations. In addition, Corynascus kuwaitiensis, Cochliobolus sp. and Ceratobasidium sp. were also abundant in the three rhizosphere samples. Previously, these were also found in the root zones of date palms [63,64], agave [27] and grasses [64,65] that are widely grown in arid land ecosystem.

In case of bacterial communities, Acidobacteria, Actinobacteria, Bacteroidetes, and Proteobacteria were highly abundant bacterial phyla. These are a few of the dominant bacterial species found in metagenomic dataset obtained from various plants and rhizospheres [57]. Similarly, increased abundance of Proteobacteria and decreased presence of Acidobacteria in the plant-rhizosphere samples with respect to different hosts were previously found with Agave species [27], suggesting a major community structure associated with the arid land plants. These have also been reported in some of the important medicinal plants, such as Panax ginseng [66], Thymus zygis [36], Polygonum cuspidatum [33], Rhododendron arboretum [35], Sapindus saponaria [53], Taxus baccata and Aloe vera [34,67]. Nonetheless, distribution of phyla including Chloroflexi, Planctomycetes, and Firmicutes in C. austroarabica rhizosphere and Cyanobacteria in A. obesum rhizosphere were significantly different, suggesting host-specific microbe management as indicated by Berendsen et al. [17]. The presence of a considerably higher number of "unidentified" sequences in bacteria might be due to (i) presence of a large number of sequences of uncultured microbes, (ii) presence of less sequenced microbial genomes, and/or (iii) absence of related orthologous nucleotide sequences in NCBI $[16,68]$. Since these plant species have been analyzed for the first time, unidentified sequences could not be associated with the potential survival of these three plants in harsh environmental conditions.

The holobiont (plants and their microbiota) plays a collective role in intergenic function and development of ecological niche. In this reciprocal interaction, production of bioactive metabolites, including extracellular enzymes and phytohormones, can subsequently pave the way for viable growth of the hosts $[15,69]$. These extracellular enzymes target various macromolecules, such as carbohydrates, lignin, organic phosphate, proteins, and sugar-based polymers, for their degradation into transportable products throughout the cells and to continue heterotopic metabolism [70]. In addition to establishing an association with host, these enzymes also initiate the action of extracellular hydrolysis to counteract plant pathogenic infection [14]. We found considerable higher concentrations of cellulases, glucosidases, esterase, and ACC deaminase in the rhizosphere samples of $A$. dhufarensis. However, phosphatase and IAA were high in A. obesum. Cellulase allows the bioconversion of cellulose and its modification into simple carbohydrates that act as carbon source for microbes [71]. The glucosidase enzyme hydrolyses starch and glycogen and converts them into monomers of carbohydrates [72]. Along 
with cellulase, glucosidase also plays an important role in providing carbon sources for the plants. Similarly, phosphatase degrades phosphoric acid monoesters into phosphate ions and alcohol [73]. Phosphate is one of the most important macronutrients of plant and plays diverse roles in plant growth and development, including root development and colonization of rhizospheric microbes $[4,74,75]$. Therefore, the presence of cellulase, glucosidase, and phosphatase in rhizosphere possess considerable significance. These enzymes, along with IAA production by associated microflora, have a high impact on the plant health and fitness against abiotic stresses [15,48]. In addition, higher ACC deaminase in A. dhufarensis can be attributed to abundance of Bacteroidetes, which have been shown extensively to produce ACC deaminase in rhizosphere [76,77]. IAA, on the other hand, was high in the rhizosphere of A. obesum, which could contribute to the abundance of Actinobacteria. Actinobacteria are known to produce IAA, as previous studies have shown $[15,78]$. This could also be attributed to survivability potentials of these three plant species during low water and nutrient availability.

In conclusion, the current results provide a genomic basis to enhance our understanding of these complex and dynamic microbial interactions with plants of sub-tropical arid ecosystems. Overall, our results are in parallel with recent metagenomic data on diversity of microbiomes associated with dry tropical to arid land plants. These plant species were studied for the first time. The identification of specific taxa, particularly at species level, can provide a new insight for future research on the associated functions and reciprocation of enriched species in rhizosphere of these medicinally important plants. Furthermore, we also assume that the secretion of exozymes and essential metabolites at microbial community level can enhance the ability of these plant species to withstand harsh sub-tropical environmental conditions.

Supplementary Materials: The following are available online at http://www.mdpi.com/2076-2607/8/2/213/s1, Table S1. MiSeq output summary for ITS and 16S rDNA of the rhizosphere region of the plant species. Table S2. Merging pre-processing \& clustering of the data obtained from MiSeq data and the associated quality parameters. Table S3. Two-way ANOVA of the diversity of the ITS and 16S rDNA datasets. Table S4 Fungal OTUs showing the shared taxonomic assignments of $A$. dhufarensis, A. obesum and C. austroarabica. Table S5. Distribution of various phyla in the bacterial communities in the rhizosphere of A. dhufarensis, A. obesum and C. austroarabica. Table S6. Distribution of various species in the bacterial communities in the rhizosphere of $A$. dhufarensis, A. obesum and C. austroarabica. Figure S1. Calculated rarefaction curves of the observed OTUs (sequences that possess above $97 \%$ similarity are defined as one OTU) richness in rhizosphere soil samples of A. dhufarensis, A. obesum and C. austroarabica. Figure S2. The principal coordinate analyses (PCoA) of pairwise Bray-Curtis distance matrixes of filtered OTU tables for the fungal and bacterial communities in the rhizosphere of A. obesum, A. dhufarensis and C. austroarabica plant species.

Author Contributions: A.L.K. and S.A. planned, performed and wrote the research and its findings; A.N.A.-R. performed the DNA extraction; Y.N.C. and R.M.M.A. analyzed the data; T.K.M. revised the manuscript; A.A.-H. and A.A.-R. arranged the experimental resources; D.P.S. edited and arranged the experimental resources the manuscript. All authors have read and agreed to the published version of the manuscript.

Funding: This work was financially supported by the Oman Research Council, Open Research Grant Project (ORG/EBR/15/007). The funders had no role in study design, data collection and analysis, decision to publish, or preparation of the manuscript.

Conflicts of Interest: The authors declare no conflict of interest.

\section{References}

1. Nothers, M.; Segev, N.; Kreyling, J.; Hjazin, A.; Groner, E. Desert Vegetation Forty Years after an Oil Spill. J. Environ. Qual. 2017, 46, 568-575. [CrossRef] [PubMed]

2. Ardley, J. Legumes of the Thar desert and their nitrogen fixing Ensifer symbionts. Plant Soil 2017, 410, 517-520. [CrossRef]

3. Mohanta, T.K.; Bae, H. Functional genomics and signaling events in mycorrhizal symbiosis. J. Plant Interact. 2015, 10. [CrossRef]

4. Pudake, R.N.; Mehta, C.M.; Mohanta, T.K.; Sharma, S.; Varma, A.; Sharma, A.K. Expression of four phosphate transporter genes from Finger millet (Eleusine coracana L.) in response to mycorrhizal colonization and Pi stress. 3 Biotech 2017, 7. [CrossRef] [PubMed] 
5. Knief, C.; Delmotte, N.; Chaffron, S.; Stark, M.; Innerebner, G.; Wassmann, R.; von Mering, C.; Vorholt, J.A. Metaproteogenomic analysis of microbial communities in the phyllosphere and rhizosphere of rice. ISME J. 2012, 6, 1378-1390. [CrossRef] [PubMed]

6. Andrews, J.H.; Harris, R.F. The Ecology and Biogeography of Microorganisms on Plant Surfaces. Annu. Rev. Phytopathol. 2000, 38, 145-180. [CrossRef]

7. Lindow, S.E.; Brandl, M.T. Microbiology of the Phyllosphere. Appl. Environ. Microbiol. 2003, 69, $1875-1883$. [CrossRef]

8. Bulgarelli, D.; Schlaeppi, K.; Spaepen, S.; van Themaat, E.V.L.; Schulze-Lefert, P. Structure and Functions of the Bacterial Microbiota of Plants. Annu. Rev. Plant Biol. 2013, 64, 807-838. [CrossRef]

9. Humphrey, P.T.; Nguyen, T.T.; Villalobos, M.M.; Whiteman, N.K. Diversity and abundance of phyllosphere bacteria are linked to insect herbivory. Mol. Ecol. 2014, 23, 1497-1515. [CrossRef]

10. Ritpitakphong, U.; Falquet, L.; Vimoltust, A.; Berger, A.; Métraux, J.-P.; L'Haridon, F. The microbiome of the leaf surface of Arabidopsis protects against a fungal pathogen. New Phytol. 2016, 210, 1033-1043. [CrossRef]

11. Strong, P.J.; Claus, H. Laccase: A Review of Its Past and Its Future in Bioremediation. Crit. Rev. Environ. Sci. Technol. 2011, 41, 373-434. [CrossRef]

12. Arnosti, C. Microbial Extracellular Enzymes and their Role in Dissolved Organic Matter Cycling. In Aquatic Ecology; Findlay, S.E.G., Sinsabaugh, R.L.B.T.-A.E., Eds.; Academic Press: Burlington, NC, Canada, 2003; pp. 315-342. ISBN 978-0-12-256371-3.

13. Loperena, L.; Soria, V.; Varela, H.; Lupo, S.; Bergalli, A.; Guigou, M.; Pellegrino, A.; Bernardo, A.; Calviño, A.; Rivas, F.; et al. Extracellular enzymes produced by microorganisms isolated from maritime Antarctica. World J. Microbiol. Biotechnol. 2012, 28, 2249-2256. [CrossRef]

14. Leo, V.V.; Passari, A.K.; Joshi, J.B.; Mishra, V.K.; Uthandi, S.; Ramesh, N.; Gupta, V.K.; Saikia, R.; Sonawane, V.C.; Singh, B.P. A Novel Triculture System (CC3) for Simultaneous Enzyme Production and Hydrolysis of Common Grasses through Submerged Fermentation. Front. Microbiol. 2016, 7, 447. [CrossRef] [PubMed]

15. Khan, A.L.; Al-Harrasi, A.; Al-Rawahi, A.; Al-Farsi, Z.; Al-Mamari, A.; Waqas, M.; Asaf, S.; Elyassi, A.; Mabood, F.; Shin, J.-H.; et al. Endophytic Fungi from Frankincense Tree Improves Host Growth and Produces Extracellular Enzymes and Indole Acetic Acid. PLoS ONE 2016, 11, e0158207. [CrossRef] [PubMed]

16. Vandenkoornhuyse, P.; Quaiser, A.; Duhamel, M.; Le Van, A.; Dufresne, A. The importance of the microbiome of the plant holobiont. New Phytol. 2015, 206, 1196-1206. [CrossRef]

17. Berendsen, R.L.; Pieterse, C.M.J.; Bakker, P.A.H.M. The rhizosphere microbiome and plant health. Trends Plant Sci. 2012, 17, 478-486. [CrossRef]

18. Pershina, E.V.; Ivanova, E.A.; Korvigo, I.O.; Chirak, E.L.; Sergaliev, N.H.; Abakumov, E.V.; Provorov, N.A.; Andronov, E.E. Investigation of the core microbiome in main soil types from the East European plain. Sci. Total Environ. 2018, 631-632, 1421-1430. [CrossRef]

19. Warren-Rhodes, K.; Lee, K.; Archer, S.; Lacap, D.; Ng-Boyle, L.; Wttergreen, D.; Zacny, K.; Demergasso, C.; Moersch, J.; Chong, G.; et al. Soil microbial habitats in an extreme desert Mars-analogue environment. bioRxiv 2018, 269605. [CrossRef]

20. Mandakovic, D.; Maldonado, J.; Pulgar, R.; Cabrera, P.; Gaete, A.; Urtuvia, V.; Seeger, M.; Cambiazo, V.; González, M. Microbiome analysis and bacterial isolation from Lejía Lake soil in Atacama Desert. Extremophiles 2018, 22, 665-673. [CrossRef]

21. Marasco, R.; Rolli, E.; Ettoumi, B.; Vigani, G.; Mapelli, F.; Borin, S.; Abou-Hadid, A.F.; El-Behairy, U.A.; Sorlini, C.; Cherif, A.; et al. A Drought Resistance-Promoting Microbiome Is Selected by Root System under Desert Farming. PLoS ONE 2012, 7, e48479. [CrossRef]

22. Crits-Christoph, A.; Robinson, C.K.; Barnum, T.; Fricke, W.F.; Davila, A.F.; Jedynak, B.; McKay, C.P.; DiRuggiero, J. Colonization patterns of soil microbial communities in the Atacama Desert. Microbiome 2013, 1, 28. [CrossRef] [PubMed]

23. Finkel, O.M.; Delmont, T.O.; Post, A.F.; Belkin, S. Metagenomic Signatures of Bacterial Adaptation to Life in the Phyllosphere of a Salt-Secreting Desert Tree. Appl. Environ. Microbiol. 2016, 82, 2854-2861. [CrossRef] [PubMed]

24. Saleem, M.; Law, A.D.; Sahib, M.R.; Pervaiz, Z.H.; Zhang, Q. Impact of root system architecture on rhizosphere and root microbiome. Rhizosphere 2018, 6, 47-51. [CrossRef] 
25. Pérez-Jaramillo, J.E.; Carrión, V.J.; Bosse, M.; Ferrão, L.F.V.; de Hollander, M.; Garcia, A.A.F.; Ramírez, C.A.; Mendes, R.; Raaijmakers, J.M. Linking rhizosphere microbiome composition of wild and domesticated Phaseolus vulgaris to genotypic and root phenotypic traits. ISME J. 2017, 11, 2244-2257. [CrossRef] [PubMed]

26. Chaparro, J.M.; Badri, D.V.; Vivanco, J.M. Rhizosphere microbiome assemblage is affected by plant development. ISME J. 2014, 8, 790-803. [CrossRef] [PubMed]

27. Coleman-Derr, D.; Desgarennes, D.; Fonseca-Garcia, C.; Gross, S.; Clingenpeel, S.; Woyke, T.; North, G.; Visel, A.; Partida-Martinez, L.P.; Tringe, S.G. Plant compartment and biogeography affect microbiome composition in cultivated and native Agave species. New Phytol. 2016, 209, 798-811. [CrossRef]

28. Li, J.; Zhao, G.-Z.; Chen, H.-H.; Wang, H.-B.; Qin, S.; Zhu, W.-Y.; Xu, L.-H.; Jiang, C.-L.; Li, W.-J. Antitumour and antimicrobial activities of endophytic streptomycetes from pharmaceutical plants in rainforest. Lett. Appl. Microbiol. 2008, 47, 574-580. [CrossRef]

29. Zhao, K.; Penttinen, P.; Chen, Q.; Guan, T.; Lindström, K.; Ao, X.; Zhang, L.; Zhang, X. The rhizospheres of traditional medicinal plants in Panxi, China, host a diverse selection of actinobacteria with antimicrobial properties. Appl. Microbiol. Biotechnol. 2012, 94, 1321-1335. [CrossRef]

30. Zhao, K.; Penttinen, P.; Guan, T.; Xiao, J.; Chen, Q.; Xu, J.; Lindström, K.; Zhang, L.; Zhang, X.; Strobel, G.A. The Diversity and Anti-Microbial Activity of Endophytic Actinomycetes Isolated from Medicinal Plants in Panxi Plateau, China. Curr. Microbiol. 2011, 62, 182-190. [CrossRef]

31. Wu, L.; Wang, H.; Zhang, Z.; Lin, R.; Zhang, Z.; Lin, W. Comparative Metaproteomic Analysis on Consecutively Rehmannia glutinosa-Monocultured Rhizosphere Soil. PLoS ONE 2011, 6, e20611. [CrossRef]

32. Qi, X.; Wang, E.; Xing, M.; Zhao, W.; Chen, X. Rhizosphere and non-rhizosphere bacterial community composition of the wild medicinal plant Rumex patientia. World J. Microbiol. Biotechnol. 2012, 28, 2257-2265. [CrossRef] [PubMed]

33. Hao, D.; Ma, P.; Mu, J.; Chen, S.; Xiao, P.; Peng, Y.; Huo, L.; Xu, L.; Sun, C. De novo characterization of the root transcriptome of a traditional Chinese medicinal plant Polygonum cuspidatum. Sci. China Life Sci. 2012, 55, 452-466. [CrossRef] [PubMed]

34. Akinsanya, M.A.; Goh, J.K.; Lim, S.P.; Ting, A.S.Y. Metagenomics study of endophytic bacteria in Aloe vera using next-generation technology. Genomics Data 2015, 6, 159-163. [CrossRef] [PubMed]

35. Debnath, R.; Yadav, A.; Gupta, V.K.; Singh, B.P.; Handique, P.J.; Saikia, R. Rhizospheric Bacterial Community of Endemic Rhododendron arboreum Sm. Ssp. delavayi along Eastern Himalayan Slope in Tawang. Front. Plant Sci. 2016, 7, 1345. [CrossRef] [PubMed]

36. Pascual, J.; Blanco, S.; García-López, M.; García-Salamanca, A.; Bursakov, S.A.; Genilloud, O.; Bills, G.F.; Ramos, J.L.; van Dillewijn, P. Assessing Bacterial Diversity in the Rhizosphere of Thymus zygis Growing in the Sierra Nevada National Park (Spain) through Culture-Dependent and Independent Approaches. PLoS ONE 2016, 11, e0146558. [CrossRef] [PubMed]

37. Favell, P. Aloe dhufarensis: The miracle Aloe of Oman. Cact. Succ. J. 1995, 67, 35-36.

38. Marwah, R.G.; Fatope, M.O.; Mahrooqi, R.A.; Varma, G.B.; Abadi, H.A.; Al-Burtamani, S.K.S. Antioxidant capacity of some edible and wound healing plants in Oman. Food Chem. 2007, 101, 465-470. [CrossRef]

39. Hossain, M.A. A review on Adenium obesum: A potential endemic medicinal plant in Oman. Beni-Suef Univ. J. Basic Appl. Sci. 2018, 7, 559-563. [CrossRef]

40. Adhikari, P.; Shukla, M.K.; Mexal, J.G.; Sharma, P. Assessment of the soil physical and chemical properties of desert soils irrigated with treated wastewater using principal component analysis. Soil Sci. 2011, 176, 356-366. [CrossRef]

41. Edgar, R.C. UPARSE: Highly accurate OTU sequences from microbial amplicon reads. Nat. Methods 2013, 10, 996. [CrossRef]

42. Deshpande, V.; Wang, Q.; Greenfield, P.; Charleston, M.; Porras-Alfaro, A.; Kuske, C.R.; Cole, J.R.; Midgley, D.J.; Tran-Dinh, N. Fungal identification using a Bayesian classifier and the Warcup training set of internal transcribed spacer sequences. Mycologia 2016, 108, 1-5. [CrossRef] [PubMed]

43. DeSantis, T.Z.; Hugenholtz, P.; Larsen, N.; Rojas, M.; Brodie, E.L.; Keller, K.; Huber, T.; Dalevi, D.; Hu, P.; Andersen, G.L. Greengenes, a Chimera-Checked 16S rRNA Gene Database and Workbench Compatible with ARB. Appl. Environ. Microbiol. 2006, 72, 5069. [CrossRef] [PubMed]

44. Dhariwal, A.; Chong, J.; Habib, S.; King, I.L.; Agellon, L.B.; Xia, J. MicrobiomeAnalyst: A web-based tool for comprehensive statistical, visual and meta-analysis of microbiome data. Nucleic Acids Res. 2017, 45, W180-W188. [CrossRef] [PubMed] 
45. Oksanen, J.; Blanchet, G.; Friendly, M.; Kindt, R.; Legendre, P.; McGlinn, D.; Minchin, P.; O’Hara, R.; Simpson, G.; Solymos, P.; et al. Ordination Methods, Diversity Analysis and Other Functions for Community and Vegetation Ecologists. Version 2.5-6. Available online: https:/cran.r-project.org/web/packages/vegan/ index.html (accessed on 25 December 2019).

46. Canonical Correlation Analysis. Applied Multivariate Statistical Analysis; Härdle, W., Simar, L., Eds.; Springer Berlin Heidelberg: Berlin/Heidelberg, Germany, 2007; pp. 321-330. ISBN 978-3-540-72244-1.

47. Marx, M.-C.; Wood, M.; Jarvis, S.C. A microplate fluorimetric assay for the study of enzyme diversity in soils. Soil Biol. Biochem. 2001, 33, 1633-1640. [CrossRef]

48. Shaharoona, B.; Arshad, M.; Zahir, Z.A. Effect of plant growth promoting rhizobacteria containing ACC-deaminase on maize (Zea mays L.) growth under axenic conditions and on nodulation in mung bean (Vigna radiata L.). Lett. Appl. Microbiol. 2006, 42, 155-159. [CrossRef]

49. Lundberg, D.S.; Lebeis, S.L.; Paredes, S.H.; Yourstone, S.; Gehring, J.; Malfatti, S.; Tremblay, J.; Engelbrektson, A.; Kunin, V.; Rio, T.G.d.; et al. Defining the core Arabidopsis thaliana root microbiome. Nature 2012, 488, 86. [CrossRef]

50. Pieterse, C.M.J.; de Jonge, R.; Berendsen, R.L. The Soil-Borne Supremacy. Trends Plant Sci. 2016, 21, 171-173. [CrossRef]

51. Köberl, M.; Schmidt, R.; Ramadan, E.M.; Bauer, R.; Berg, G. The microbiome of medicinal plants: Diversity and importance for plant growth, quality and health. Front. Microbiol. 2013, 4, 400. [CrossRef]

52. Tian, B.-Y.; Cao, Y.; Zhang, K.-Q. Metagenomic insights into communities, functions of endophytes, and their associates with infection by root-knot nematode, Meloidogyne incognita, in tomato roots. Sci. Rep. 2015, 5, 17087. [CrossRef]

53. Garcia, A.; Polonio, J.C.; Polli, A.D.; Santos, C.M.; Rhoden, S.A. Rhizosphere bacteriome of the medicinal plant Sapindus saponaria L. revealed by pyrosequencing. Genet. Mol. Res. 2016, 15, gmr15049020. [CrossRef]

54. Berg, G.; Rybakova, D.; Grube, M.; Köberl, M. The plant microbiome explored: Implications for experimental botany. J. Exp. Bot. 2016, 67, 995-1002. [CrossRef]

55. Kembel, S.W.; Eisen, J.A.; Pollard, K.S.; Green, J.L. The Phylogenetic Diversity of Metagenomes. PLoS ONE 2011, 6, e23214. [CrossRef]

56. Horton, M.W.; Bodenhausen, N.; Beilsmith, K.; Meng, D.; Muegge, B.D.; Subramanian, S.; Vetter, M.M.; Vilhjálmsson, B.J.; Nordborg, M.; Gordon, J.I.; et al. Genome-wide association study of Arabidopsis thaliana leaf microbial community. Nat. Commun. 2014, 5, 5320. [CrossRef] [PubMed]

57. Lebeis, S.L.; Paredes, S.H.; Lundberg, D.S.; Breakfield, N.; Gehring, J.; McDonald, M.; Malfatti, S.; Glavina del Rio, T.; Jones, C.D.; Tringe, S.G.; et al. Salicylic acid modulates colonization of the root microbiome by specific bacterial taxa. Science 2015, 349, 860-864. [CrossRef] [PubMed]

58. Leibold, M.A.; McPeek, M.A. Coexistence of the niche and neutral perspectives in community ecology. Ecology 2006, 87, 1399-1410. [CrossRef]

59. Nasseri, M.A.; Behravesh, S.; Allahresani, A. Essential oil composition of Cleome heratensis (Capparaceae) at different growing stages. Iran. Chem. Commun. 2017, 5, 364-371.

60. Abubakar, S.; Akanbi, B.O.; Osuji, C.; Olajide, O.O.; Phillip, E.A. Evaluation of pharmacological potentials of Jatropha curcas Linn sap Euphobiaceae family. Pharm. Biol. Eval. 2016, 3, 334-342.

61. Guo, M.; Gong, Z.; Miao, R.; Su, D.; Li, X.; Jia, C.; Zhuang, J. The influence of root exudates of maize and soybean on polycyclic aromatic hydrocarbons degradation and soil bacterial community structure. Ecol. Eng. 2017, 99, 22-30. [CrossRef]

62. Rasmann, S.; Turlings, T.C.J. Root signals that mediate mutualistic interactions in the rhizosphere. Curr. Opin. Plant Biol. 2016, 32, 62-68. [CrossRef]

63. Porras-Alfaro, A.; Herrera, J.; Natvig, D.O.; Lipinski, K.; Sinsabaugh, R.L. Diversity and distribution of soil fungal communities in a semiarid grassland. Mycologia 2011, 103, 10-21. [CrossRef]

64. Al-Yahyai, R.; Khan, M. Date Palm Status and Perspective in Oman. In Date Palm Genetic Resources and Utilization: Volume 2: Asia and Europe; Springer: Dordrecht, The Netherlands, 2015; pp. 207-240. ISBN 978-94-017-9706-1.

65. Loro, M.; Valero-Jiménez, C.A.; Nozawa, S.; Márquez, L.M. Diversity and composition of fungal endophytes in semiarid Northwest Venezuela. J. Arid Environ. 2012, 85, 46-55. [CrossRef] 
66. Tan, Y.; Cui, Y.; Li, H.; Kuang, A.; Li, X.; Wei, Y.; Ji, X. Diversity and composition of rhizospheric soil and root endogenous bacteria in Panax notoginseng during continuous cropping practices. J. Basic Microbiol. 2017, 57, 337-344. [CrossRef] [PubMed]

67. Golinska, P.; Wypij, M.; Agarkar, G.; Rathod, D.; Dahm, H.; Rai, M. Endophytic actinobacteria of medicinal plants: Diversity and bioactivity. Antonie Van Leeuwenhoek 2015, 108, 267-289. [CrossRef] [PubMed]

68. Randle-Boggis, R.J.; Helgason, T.; Sapp, M.; Ashton, P.D. Evaluating techniques for metagenome annotation using simulated sequence data. FEMS Microbiol. Ecol. 2016, 92, fiw095. [CrossRef] [PubMed]

69. Quiza, L.; St-Arnaud, M.; Yergeau, E. Harnessing phytomicrobiome signaling for rhizosphere microbiome engineering. Front. Plant Sci. 2015, 6, 507. [CrossRef] [PubMed]

70. Wingender, J.; Neu, T.; Flemming, H. What are bacterial extracellular polymeric substances. In Microbial Extracellular Polymeric Substances; Wingender, J.N., Thomas, R., Flemming, H.-C., Eds.; Springer: Dordrecht, The Netherlands, 1999; pp. 1-19.

71. Walker, L.P.; Wilson, D.B. Enzymatic hydrolysis of cellulose: An overview. Bioresour. Technol. 1991, 36, 3-14. [CrossRef]

72. Kim, Y.-M.; Saburi, W.; Yu, S.; Nakai, H.; Maneesan, J.; Kang, M.-S.; Chiba, S.; Kim, D.; Okuyama, M.; Mori, H.; et al. A novel metabolic pathway for glucose production mediated by $\alpha$-glucosidase-catalyzed conversion of 1,5-anhydrofructose. J. Biol. Chem. 2012, 287, 22441-22444. [CrossRef]

73. Yuan, H.; Li, N.; Lai, Y. Evaluation of in Vitro Models for Screening Alkaline Phosphatase- Mediated Bioconversion of Phosphate Ester Prodrugs. Drug Metab. Diposition 2009, 37, 1443-1447. [CrossRef]

74. Razaq, M.; Zhang, P.; Shen, H. Salahuddin Influence of nitrogen and phosphorous on the growth and root morphology of Acer mono. PLoS ONE 2017, 12, e0171321. [CrossRef]

75. Abdolzadeh, A.; Wang, X.; Veneklaas, E.J.; Lambers, H. Effects of phosphorus supply on growth, phosphate concentration and cluster-root formation in three Lupinus species. Ann. Bot. 2010, 105, 365-374. [CrossRef]

76. Lee, M.H.; Lee, S.-W. Bioprospecting potential of the soil metagenome: Novel enzymes and bioactivities. Genom. Inform. 2013, 11, 114-120. [CrossRef] [PubMed]

77. Rasche, F.; Marco-Noales, E.; Velvis, H.; van Overbeek, L.S.; López, M.M.; van Elsas, J.D.; Sessitsch, A. Structural characteristics and plant-beneficial effects of bacteria colonizing the shoots of field grown conventional and genetically modified T4-lysozyme producing potatoes. Plant Soil 2006, 289, 123-140. [CrossRef]

78. Goudjal, Y.; Toumatia, O.; Sabaou, N.; Barakate, M.; Mathieu, F.; Zitouni, A. Endophytic actinomycetes from spontaneous plants of Algerian Sahara: Indole-3-acetic acid production and tomato plants growth promoting activity. World J. Microbiol. Biotechnol. 2013, 29, 1821-1829. [CrossRef] [PubMed] 